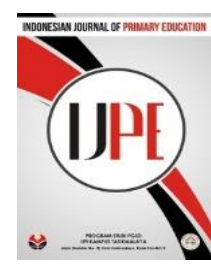

\title{
Penggunaan Metode Servqual dalam Pengukuran Kualitas Layanan Pendidikan
}

\author{
Suhendra ${ }^{1}$, Raden Roro Suci Nurdianti ${ }^{2}$ \\ Universitas Siliwangi \\ *Corresponding author: suhendra.ekonomi@gmail.com, radenrorosucinurdianti@unsil.ac.id \\ Diterima 20 Agustus 2018; Direview 18 September 2018; Diterima 15 Oktober 2018 \\ Diterbitkan online 28 Desember 2018
}

\begin{abstract}
The goals of educational institutions can be seen from the number of applicants or the number of students at the institutions. If the institutions have a good image in the society, it will increase the number of applicants to take study on the institutions. In the education service industry, the most effective promotion is a recommendation from the user for the satisfaction of services received during transactions and services after the transaction. Therefore, the academic services played an important role in the sustainability of an educational institution.

The service quality model which has been used as a reference in service marketing research is a Servqual (service quality) model developed by Parasuraman, Zeithaml, and Berry. Servqual as a reference for measuring service quality is with 5 dimensions: (1) reliability, (2) assurance, (3) responsiveness, (4) empathy and (5) tangibles. This model can be applied in various aspects contained in services / services provided by each institution. This study aims to discuss how the use of the Servqual method is applied in measuring the quality of education services.
\end{abstract}

Keywords: Academic; Service; Quality; Servqual;Measurement

Abstrak

Keberhasilan suatu lembaga pendidikan salah satunya dapat terlihat dari jumlah pendaftar atau jumlah siswa pada lembaga tersebut. Semakin baik citra lembaga di masyarakat, akan berdampak pada meningkatnya jumlah pendaftar untuk mengecap pendidikan di lembaga tersebut. Dalam Industri jasa Pendidikan, promosi yang paling efektif adalah rekomendasi dari pengguna atas kepuasan dari layanan yang diterima pada saat bertransaksi maupun layanan setelah transaksi dilakukan. Oleh karena itu, layanan akademik yang diberikan memegang peranan penting dalam keberlangsungan suatu lembaga pendidikan.

Model kualitas pelayanan yang hingga kini banyak dijadikan sebagai acuan dalam riset pemasaran jasa adalah model servqual (service quality) yang dikembangkan oleh Parasuraman, Zeithaml, dan Berry. Servqual yang dijadikan acuan untuk mengukur kualitas pelayanan adalah dengan 5 dimensi : (1) kehandalan (reliability), (2) jaminan (assurance), (3) daya tanggap (responsiveness), (4) empati (empathy) dan (5) bukti langsung (tangibles). Model ini dapat diterapkan di berbagai aspek yang terdapat pada pelayanan/jasa yang disediakan oleh lembaga masing-masing. Kajian ini bertujuan untuk membahas bagaimana penggunaan metode Servqual ini diterapkan dalam pengukuran kualitas layanan pendidikan

Kata Kunci: Kualitas;Layanan;Akademik; Pengukuran; Servqual.

PENDAHULUAN

Industri Jasa Pendidikan yang semakin pesat beberapa tahun terakhir, menuntut masing-masing institusi penyelenggara pendidikan untuk memberikan pelayanan yang sebanding dengan berbagai variasi harga yang ditawarkan. Baik institusi pendidikan negeri maupun swasta, saling berlomba menghimpun siswa sebanyakbanyaknya. Semakin baik citra institusi pendidikan tersebut, maka jumlah pendaftar pun akan semakin meningkat.
Kepuasan merupakan ketiadaan perbedaan antara harapan yang dimiliki dan unjuk kerja yang senyatanya diterima. Apabila harapan tinggi, sementara unjuk kerja biasa-biasa saja, kepuasan tidak akan tercapai. Sebaliknya, apabila unjuk kerja melebihi dari yang diharapkan, kepuasan akan meningkat. (Yazid, 2008 : 55). Oleh karena itu, kepuasan dari layanan yang diterima, memegang peranan yang sangat penting demi peningkatan citra 
lembaga, termasuk didalamnya lembaga/institusi penyelenggara pendidikan.

Dalam analisis manajemen, terdapat berbagai metode dan model pengukuran kualitas pada industri jasa. Salah satu model kualitas pelayanan yang hingga kini banyak dijadikan sebagai acuan dalam riset pemasaran jasa adalah model servqual (service quality) yang dikembangkan oleh Parasuraman, Zeithaml, dan Berry.

Model ini dapat diterapkan di berbagai aspek yang terdapat pada pelayanan/jasa yang disediakan oleh lembaga masing-masing. Termasuk didalamnya yaitu lembaga Pendidikan.

\section{KAJIAN PUSTAKA}

Kualitas Jasa harus dimulai dari kebutuhan pelanggan dan berakhir pada persepsi pelanggan (Kotler, 2009). Pelanggan merupakan penilai utama tingkat kualitas jasa suatu perusahaan.

Pengukuran kualitas jasa dalam model Servqual didasarkan pada skala multi-item yang dirancang untuk mengukur harapan dan persepsi pelanggan, serta gap diantara keduanya dalam dimensi-dimensi utama kualitas jasa (Tjiptono, 2007).

Pada penelitian awalnya, Parasuraman, et al., (1985) mengidentifikasi sepuluh dimensi pokok, yakni reliabilitas, daya tanggap, kompetensi, akses, kesopanan, komunikasi, kredibilitas, keamanan, kemampuan memahami pelanggan, dan bukti fisik. Namun pada penelitian selanjutnya, sepuluh dimensi tersebut dirangkum dan disempurnakan. Untuk aspek kesopanan, kompetensi, kredibilitas, keamanan, dikategorikan sebagai aspek jaminan (assurance). Sedangkan akses, komunikasi, dan kemampuan memahami pelanggan dikategorikan sebagai empati (empathy). Secara keseluruhan, terdapat lima dimensi utama yaitu :

1. Reliabilitas, (reliability) yakni kemampuan memberikan layanan yang disajikan dengan segera, akurat, dan memuaskan.

2. Daya tanggap (responsiveness) yaitu keinginan staff untuk membantu para pelanggan dan memberikan layanan dengan tanggap

3. Jaminan (assurance), mencakup pengetahuan, kompetensi, kesopanan, dan sifat dapat dipercaya yang dimiliki para staf

4. Empati (Empathy), meliputi kemudahan dalam menjalin relasi, komunikasi yang baik, perhatian pribadi, dan pemahaman atas kebutuhan individual para pelanggan

5. Bukti fisik (tangibles) meliputi fasilitas fisik, perlengkapan, pegawai, dan sarana komunikasi.

Lima dimensi kualitas jasa pada Servqual dijabarkan ke 22 item kuisioner yang berisi atribut harapan dan atribut persepsi. Variabelvariabel tersebut disusun dalam pernyataan yang menggunakan skaa likert dengan 7 poin pengukuran. Skor yang dihitung adalah selisih antara persepsi dan harapan terkait masingmasing pernyataan, atau dapat dirumuskan:

Skor Servqual $=$ Skor Persepsi - Skor Harapan 
Kualitas jasa pada lembaga pada kelima dimensi tersebut dapat dihitung untuk semua responden, dengan cara menghitung rata-rata skor Servqual mereka pada pernyataan yang mencerminkan setiap dimensi. Adapun atribut dan dimensi ke 22 item Servqual dapat dilihat pada tabel 1 .

\section{Tabel 1}

Atribut dan Dimensi Servqual

Sumber : Zeithaml, et al. (1990)

\begin{tabular}{|c|c|c|}
\hline No. & Atribut & Dimensi \\
\hline 1. & $\begin{array}{l}\text { Jika menjanjikan sesuatu di waktu tertentu, pasti } \\
\text { direalisasikan. }\end{array}$ & Reliabilitas \\
\hline 2. & $\begin{array}{l}\text { Bersikap simpatik dan sanggup menenangkan } \\
\text { pelanggan jika ada masalah }\end{array}$ & Reliabilitas \\
\hline 3. & Jasa disampaikan secara benar sejak kali pertama & Reliabilitas \\
\hline 4. & $\begin{array}{l}\text { Jasa disampaikan sesuai dengan waktu yang } \\
\text { dijanjikan }\end{array}$ & Reliabilitas \\
\hline 5. & Sistem pencatatan yang akurat dan bebas kesalahan & Reliabilitas \\
\hline 6. & Layanan yang segera/cepat dari karyawan & Daya tanggap \\
\hline 7. & $\begin{array}{l}\text { Kepastian waktu penyampaian jasa diinformasikan } \\
\text { dengan jelas }\end{array}$ & Daya tanggap \\
\hline 8. & Karyawan yang selalu bersedia membantu pelanggan & Daya tanggap \\
\hline 9. & $\begin{array}{l}\text { Karyawan yang tidak terlampau sibuk sehingga } \\
\text { sanggup melayani pelanggan dengan cepat }\end{array}$ & Daya tanggap \\
\hline 10. & Karyawan yang terpercaya & Jaminan \\
\hline 11. & $\begin{array}{l}\text { Perasaan aman sewaktu melakukan transaksi dengan } \\
\text { karyawan penyedia jasa. }\end{array}$ & Jaminan \\
\hline 12. & Karyawan yang selalu sopan kepada pelanggan & Jaminan \\
\hline 13. & $\begin{array}{l}\text { Karyawan yang dapat menjawab pertanyaan } \\
\text { pelanggan }\end{array}$ & Jaminan \\
\hline 14. & Perhatian individual dari lembaga & Empati \\
\hline 15. & $\begin{array}{l}\text { Waktu operasi yang cocok/nyaman bagi para } \\
\text { pelanggan }\end{array}$ & Empati \\
\hline 16. & Karyawan yang memberikan perhatian personal & Empati \\
\hline 17. & $\begin{array}{l}\text { Lembaga yang memperhatikan kepentingan } \\
\text { pelanggan }\end{array}$ & Empati \\
\hline 18. & Karyawan yang memahami kebutuhan pelanggan & Empati \\
\hline 19. & Peralatan mutakhir/terbaru & Bukti Fisik \\
\hline & Fasilitas fisik yang menarik & Bukti Fisik \\
\hline & Karyawan yang berpenampilan rapi & Bukti Fisik \\
\hline 22. & Fasilitas fisik sesuai dengan jasa yang ditawarkan & Bukti Fisik \\
\hline
\end{tabular}

Skor Servqual untuk kelima dimensi yang diperoleh di rata-ratakan kembali, untuk mendapatkan ukuran kualitas jasa keseluruhan. Pada prinsipnya, data yang diperoleh dari instrument Servqual dapat dipergunakan untuk menghitung skor gap kualitas jasa pada berbagai level secara rinci seperti berikut :

1. Item-by-item analysis, yakni menghitung selisih antara persepsi dan harapan di setiap item pernyataan 


\section{Dimension-by-dimension analysis,} yakni skor persepsi setiap dimensi di rata-ratakan, dikurangi dengan skor harapan yang juga di rata-ratakan

3. Penghitungan ukuran tunggal kualitas jasa keseluruhan, yaitu dengan merataratakan skor persepsi keseluruhan kemudian dikurangi dengan skor harapan secara keseluruhan

Analisis skor gap pada Servqual ini akan membantu lembaga dalam menilai kualitas pelayanan yang diberikan, serta mengidentifikasi dimensi mana yang membutuhkan pengawasan lebih lanjut.

\section{PEMBAHASAN}

Pendidikan sebagai salah satu sektor yang bergerak dibidang jasa, selalu memerlukan peningkatan kualitas layanan dari waktu ke waktu, sebagaimana kebutuhan seluruh stakeholder yang terus bertambah seiring perkembangan teknologi dan perkembangan zaman. Kualitas yang dimaksud disini merupakan satu kesatuan sistem yang terintegrasi mulai dari manajemen kelas hingga ke manajemen sekolah secara keseluruhan. Semua ini melibatkan harapan dan persepsi dari semua pihak yang berkepentingan seperti siswa, orang tua, alumni, bahkan stakeholder lainnya.

Dalam mengevaluasi kualitas pendidikan baik secara parsial maupun secara menyeluruh, model Servqual dapat digunakan sebagai salah satu model pengukuran yang didalamnya mencakup pada pemberian layanan secara keseluruhan yang dikelompokan kedalam 5 dimensi. Dimensidimensi servqual tersebut biasanya diterapkan pada industri/perusahaan yang bergerak di bidang jasa. Untuk penerapan di sektor pendidikan, instrument servqual dapat disesuaikan dengan istilah-istilah yang lebih sesuai dengan sektor pendidikan itu sendiri. Misalkan, dengan mengganti kata "Lembaga" dengan "Sekolah", jika yang diukur adalah kualitas pada sekolah tertentu. Mengganti kata "Karyawan" dengan kata "Guru", atau bahkan mengganti kata "layanan" langsung dengan "Pembelajaran" jika memang kualitas yang dinilai adalah terkait mata pelajaran tertentu.

Penerapan model servqual dalam pendidikan sudah seringkali digunakan, namun biasanya berada pada jenjang Pendidikan Tinggi (Universitas). Beberapa penelitian terdahulu menggunakan model ini dalam menganalisis kepuasan mahasiswa. Namun, model servqual ini hanya mengukur kepuasan dari layanan yang diberikan secara umum saja. Artinya, jika pengukuran layanan pada institusi pendidikan mengarah pada halhal yang lebih spesifik seperti kurikulum, kebijakan pimpinan, serta keilmuan yang dibahas secara terperinci, maka kuisioner servqual memerlukan modifikasi lebih lanjut lagi secara terperinci.

Sebagai contoh, Khan \& Mahapatra (2007) membuat permodelan baru melalui framework awal Servqual kemudian dimodifikasi menjadi Eduqual yang didalamnya terdapat 
aspek learning outcomes dan faktor akademik lainnya secara spesifik. Namun, untuk pengukuran pelayanan akademik secara umum tentunya model awal dari Servqual juga masih dapat digunakan dalam menganalisis kualitas jasa pada sektor pendidikan.

\section{SIMPULAN}

Metode SERVQUAL pada dasarnya dapat digunakan dalam berbagai sektor jasa, termasuk jasa pendidikan. Namun untuk pengukuran yang lebih spesifik terkait akademik, metode servqual belum sampai mengukur aspek kurikulum, kebijakan, serta faktor terkait lainnya. Oleh karena itu diperlukan modifikasi lebih lanjut jika yang diukur adalah aspek yang lebih spesifik daripada kualitas layanan pendidikan.

Terdapat banyak sekali perbedaan pendapat dari para peneliti tentang pendekatan yang dipakai dalam pengukuran kualitas layanan pendidikan terhadap kepuasan pelanggan. Ini menjadi sebuah gap yang dapat menjadi kajjian lebih lanjut bagi para penulis atau peneliti yang lainnya.

\section{DAFTAR PUSTAKA}

Kotler, Philip (2009), Marketing Management, Penerjemah: Herujati Purwoko, Jilid 1, Cetakan Kesepuluh, Penerbit Erlangga: Jakarta.

Mahapatra, M.M dan Khan, M.S. (2007). A framework for analysing quality in education settings. European Journal of Engineering Education Vol. 32, No. 2, May 2007,205-217
Ratih Hurriyati. (2008). Bauran Pemasaran dan Loyalitas Konsumen. Bandung : Alfabeta

Yazid. (2008). Pemasaran Jasa : Konsep dan Implementasi. Yogyakarta : EKONISIA Fakultas Ekonomi UII

Tjiptono, Fandy. (2007). Pemasaran Jasa. Malang : Bayumedia Publishing.

Zeithaml, V.A., A. Parasuraman, dan L.L. Berry. (1990) . "Delivering Quality Service : Balancing Customer Perception \& Expectation". Simon and Schuster. New York. 